\title{
Sustainability, Competitive Advantages and Performance in the Hotel Industry: A Synergistic Relationship
}

\author{
Jorge Pereira-Moliner \\ Business Management Department, University of Alicante, Alicante, Spain \\ María D. López-Gamero \\ Business Management Department, University of Alicante, Alicante, Spain \\ Xavier Font \\ School of Hospitality and Tourism Management, University of Surrey, UK; and \\ School of Business and Economics, UiT. The Arctic University of Norway, Tromsø, Norway \\ José F. Molina-Azorín \\ Business Management Department, University of Alicante, Alicante, Spain \\ Juan José Tarí \\ Business Management Department, University of Alicante, Alicante, Spain \\ Eva M. Pertusa-Ortega \\ Business Management Department, University of Alicante, Alicante, Spain
}

Received: 20 July 2021. Revision received: 29 September 2021. Accepted: 16 November 2021

\begin{abstract}
The relationship between sustainability, competitive advantages, and performance is a topic with no conclusive results in the tourism industry. To contribute to the debate, the purpose of this study is i) to analyze the influence of sustainability on cost and differentiation competitive advantages and ii) to examine the possible synergistic relationship between sustainability and performance. Perceptual as well as hotel-specific objective performance measurements are used, such as occupancy rate, average daily rate (ADR), and revenues per available room (RevPAR), to examine all the relationships. Structural equation models based on Partial Least Squares (PLS-SEM) are applied to test all the hypotheses. Data is collected from 3-, 4- and 5-star hotels in Spain. The results show that sustainability positively and significantly influences cost and differentiation advantages, perceptual performance, ADR, and RevPAR. In addition, those hotels with these three performance variables whose values are above the median obtain a significant relationship between sustainability and performance. Consequently, there is evidence of a synergistic sustainability-performance relationship in the hotel industry. Therefore, this study offers academic evidence on the strong relationships that exist between these variables in the hotel industry. This research work analyses all three sustainability pillars (economic, environmental, and social sustainability), and the practices that best explain each of the three sustainability pillars are indicated so that hotel managers can optimize their sustainable management.
\end{abstract}

Key Words: sustainability, competitive advantage, synergy theory, performance, PLS-SEM, hospitality.

JEL Classification: M1, Q56, Z31

Reference: Pereira-Moliner, J., López-Gamero, M.D., Font, X., Molina-Azorín, J.F., Tarí, J.J. \& PertusaOrtega, E.M. (2021). Sustainability, Competitive Advantages and Performance in the Hotel Industry: A Synergistic Relationship. Journal of Tourism and Services, 23(12), 132-149. doi: 10.29036/jots.v12i23.282 


\section{JOURNAL OF TOURISM AND SERVICES}

Issue 23, volume 12, ISSN 1804-5650 (Online)

www.jots.cz

\section{Introduction}

In the last two decades, a wealth of research has studied whether, and under which conditions, sustainability is related to competitive advantage and organisational performance (Al-Ali Mubarack et al., 2020; Garriga \& Melé, 2014; Kuo et al., 2021; Loureiro et al., 2021, Orlitzky et al., 2003). However, hospitality and tourism studies have achieved no conclusive results in this area (Abughniem et al., 2020; Moneva et al., 2020; Rhou \& Singal, 2020; Theodoulidis et al., 2017). Multiple theories have been used to explain some of the inconsistent results. Instrumental theories have been used to describe/justify sustainability actions as being merely a means to an end in terms of profits or, essentially, enlightened self-interest. Such profits can be the result of maximising shareholder value and/or competitive advantages explained by a resource-based view of the company. Political theories have understood sustainability actions to be a response to stakeholder demands and, in the hospitality literature, sustainability actions have often been explained through stakeholder theory, social impact theory and/or institutional theory. Finally, normative theories have explained sustainability as a moral responsibility.

In addition, a few studies have paid attention to the possibility of whether sustainability can generate hotel performance and, in turn, whether such performance can feed forward to support the implementation of further sustainability activities (Lee \& Park, 2009; Moneva et al, 2020; Singal, 2014). However, unlike previous studies, this paper considers a synergistic relationship between sustainability and performance in the hotel industry, as this relationship only occurs in hotel companies with high levels of performance. Therefore, we contribute to the literature by examining not only the question, "Does it pay to be sustainable?" but also, "Are the most profitable hotels the most sustainable?".

Furthermore, most studies that deal with the relationship between sustainability, competitive advantages and hotel performance only focus on the environmental component of sustainability (Sánchez-Medina et al., 2016; Ramanathan et al., 2016; Tang et al., 2014), with few taking a triple bottom line approach (Garay \& Font, 2012; Ghaderi et al., 2019, Moneva et al, 2020). To overcome this gap, we use a triple bottom line approach to analyse the relationship between sustainability, competitive advantages and hotel performance, which, previously, has been scarce in the literature on tourism.

In addition, the lack of conclusive results regarding the relationship between sustainability and performance may be due to the way in which the variables have been measured, as they should fit the specific characteristics of the industry analysed (Moneva et al, 2020; Theodoulidis et al., 2017). Most studies applied to tourism have used only perceptual measures of performance (Garay \& Font, 2013; Ghaderi et al., 2019). The studies that have used objective data have focused on corporate variables, such as Return on Assets (ROA), Return on Equity (ROE), sales growth and Tobin's Q ratio (Kang et al., 2010; Zhu et al., 2014). Therefore, our further contribution is the use of perceptual and objective, hotelspecific measures (such as occupancy rate, average daily rate (ADR) and revenues per available room (RevPAR)) to capture evidence on the relation between sustainability and hotel performance.

Hence, the purposes of this paper are: i) to analyse the influence of sustainability on cost and differentiation competitive advantages; and ii) to analyse the relationship between sustainability and hotel performance and understand whether this relationship occurs only in the most profitable hotels.

The structure of this paper is as follows. Firstly, the main theories are presented regarding the relationships between sustainability, competitive advantage, and performance, together with the hypotheses. Then, the study method is explained, and the results analysed. Finally, conclusions are drawn including the main theoretical and practical implications, alongside limitations and future lines of research. 


\section{JOURNAL OF TOURISM AND SERVICES}

Issue 23, volume 12, ISSN 1804-5650 (Online)

www.jots.cz

\section{Literature review}

Sustainability is an important element to improve the competitiveness of tourist destinations. Sustainability is also important for the competitiveness of the hotel industry that will economically develop these destinations (Attila, 2016; Jurigová \& Lencsésová, 2015; Jurigová et al., 2016). An enlightening fact about the relationship between sustainability and competitiveness in the hotel industry is that investing in sustainability can improve hotel performance. The relationships between sustainability practices and hotel performance can be explained by instrumental, political or normative theories. Each theory explains different elements of the relationships; hence a holistic approach is required when we broadly consider the breadth of sustainability actions that an organisation can engage in, and the multitude of variables that can influence hotel performance. Hence, in this paper, we deliberately take an eclectic approach to inform our research framework.

First, instrumental theories see sustainability as a means by which to gain more profits. The resourcebased view states that firms that implement sustainability activities may obtain cost and differentiation competitive advantages by acquiring and developing resources and capabilities that help to develop a product or service that is difficult for competitors to imitate (Barney, 2001; Garay \& Font, 2012, 2013). Tourism organisations can selectively implement those sustainability practices that lead to competitive advantage gained from cost reductions (e.g., energy efficiency actions), even in the absence of pressure from stakeholders to broaden their range of sustainability actions (Peloza \& Papania, 2008). In the presence of stakeholder pressures, the same organisations can implement the specific sustainability practices that achieve a differentiation competitive advantage. For example, cause-related marketing provides positive reputational benefits through the association of a hotel brand with the socially responsible values held by its guests and intermediaries (Fernández-Gámez et al., 2020); the latter assume that the products from an honest company will be of high quality and this can increase their willingness to pay higher prices (Font \& McCabe, 2017).

Second, political theories see sustainability as an organisation's response to stakeholder expectations. Within this group of theories, the institutional theory interprets sustainability as a source of legitimacy and reputation among stakeholders (Farha et al., 2018; Garay \& Font, 2012). Alternatively, the stakeholder theory is based on the study of a company's relationship with individuals or groups that affect, or are affected by, the actions performed by the firm. This theory provides the basis on which researchers have argued that there is a positive influence of sustainability on hotel financial performance (Ghaderi et al., 2019; Inoue \& Lee, 2011; Kang et al., 2010; Lee \& Park, 2009; Teng et al., 2015; Theodoulidis et al., 2017). According to these authors, if the sustainability practices developed by a hotel respond to all the legitimate requests of its stakeholders (Lu et al., 2020), the hotel's performance may improve due to its improved reputation, increased cost savings and reduced legislative control. In addition to improving legitimacy and reputation with customers (Holotová et al., 2020; Streimikiene \& Ahmed, 2021), green human resource management and self-efficacy facilitate green creativity (Farooq et al, 2021), employee loyalty, the feeling of belonging to the company and a commitment to achieving objectives (Ahmed et al., 2019), which also improves organisational performance (Pham et al, 2020; Stojanovic, 2020).

Finally, normative theories take a values-based understanding of sustainability as a moral duty. Tourism organisations that act sustainably, based on normative theories, have a broader sense of responsibility not only towards themselves and their immediate stakeholders but also towards the planet (Font et al., 2016). The slack resources theory is interpreted as a normative theory because management makes a deliberate decision to allocate resources towards sustainability, rather than dedicating the resources to other activities. The slack resources theory postulates that good organisational performance allows an organisation to earmark resources for sustainability (Waddock \& Graves, 1997). The synergy theory explains the feedback loop of sustainability practices impacting on performance and that, based on the slack resources theory, in the face of increased performance, managers may also have an increased 


\section{JOURNAL OF TOURISM AND SERVICES}

Issue 23, volume 12, ISSN 1804-5650 (Online)

www.jots.cz

interest in the development of sustainable practices (Calveras, 2015; Lee \& Park, 2009). However, contrary to the slack resources theory, Moneva et al. (2020) found that, typically, higher financial performance leads to lower sustainability commitment, and concluded that a hotel's willingness to engage in sustainability practices is not determined by its current corporate financial performance. Singal (2014) found that controlling for a hotel's financial condition (and therefore access to slack resources), familyowned hotels do not invest more in sustainability, thus debunking the supposed principle of long-term orientation of family companies.

Hence, we argue that there is still much to learn about sustainability-performance synergies and, for this reason, we draw from multiple theories to remain open to overlapping explanations for our findings, while preferring to study the relationships in a single industry in order to provide more granular interpretations. The literature writing about sustainability as a source of competitive advantage, has often emphasised the opportunities for cost savings from sustainability-oriented innovations, that contribute to improved hotel performance (Garay et al., 2019; Wang et al., 2020). For instance, eco-savings can have a positive impact on performance through cost reduction, for example from water and energy reduction practices, waste recycling or the use of environmentally-friendly products (Bohdanowicz et al., 2011; Garay \& Font, 2012). In addition, sustainability practices such as promoting gender equality, facilitating work-family conciliation, and making the facilities more accessible may prevent governmental fines and penalties. In this respect, Garay and Font (2012), after studying the connection between social, environmental, and economic practices and performance, find that there is a positive impact of savings in environmental costs on performance.

In addition to the eco-savings, sustainability practices may also create a differentiation competitive advantage that impacts on performance, as a result of offering higher quality service that generates new experiences and, in so doing, creates a good image for tourism companies and enhances consumer trust (Berezan et al., 2014; González-Rodríguez et al., 2019; Levy \& Park, 2011; Lu et al., 2020; Palacios-Florencio et al., 2018; Suárez-Cebador et al., 2018; Vu \& Ngo, 2019). Therefore, considering these arguments, the academic literature from the hotel industry considers that sustainability is positively associated with cost and differentiation competitive advantages.

Sustainability results from several factors, including: i) economic practices such as the wages paid to hotel staff or the purchase of goods and services from producers; ii) environmental practices such as energy, water and waste reduction, and biodiversity conservation, which can involve suppliers, intermediaries, employees and guests; and iii) social practices such as cooperation with, or involvement in, social, cultural and social integration projects. For this research, we consider only articles focused on the hotel industry that analyse the triple bottom line; we deliberately do not include those that focus solely on environmental issues. Although a few have reported a negative, or non-significant, impact of sustainability on hotel performance (González-Rodríguez et al., 2019; Kang et al., 2010; Moneva et al., 2020; Theodoulidis et al., 2017), most authors report a positive connection between these variables (Garay \& Font, 2012, 2013; García-Rodríguez \& Armas-Cruz, 2007; Ghaderi et al., 2019; Inoue \& Lee, 2011; Kang et al., 2010; Lee \& Park, 2009; Theodoulidis et al., 2017).

This research proposes that the relationship between sustainability and performance could be synergistic, or contingent, according to the level of hotel performance. As pointed out above, the slack resources theory postulates that managers make deliberate decisions to develop sustainability practices and, therefore, companies that achieve high organisational performance levels will invest more resources in sustainability practices (Waddock \& Graves, 1997). From the point of view of synergy theory, the most profitable hotel companies may be the ones that invest the most in sustainability because such sustainability may also, subsequently, increase hotel performance (Claveras, 2015; Lee \& Park, 2009). Similarly, Singal (2014) concludes that investment in environmental sustainability matters and is in fact part of a virtuous cycle with the hotel's financial performance. However, the relationships between sustainability and performance proposed by slack resources and synergy theories may not always occur independently of the level of company performance achieved (González-Rodríguez et al., 2019; Kang et 


\section{JOURNAL OF TOURISM AND SERVICES}

Issue 23, volume 12, ISSN 1804-5650 (Online)

www.jots.cz

al., 2010; Moneva et al., 2020; Theodoulidis et al., 2017). These dissimilar results may be because an investment is required to implement sustainability measures. It is possible that the most profitable hotel companies may have a more favourable competitive position, compared to less profitable hotels, to correctly face this investment. Therefore, these arguments show a synergistic relationship between sustainability and performance.

\section{Methods and data}

As we proposed previously, we have two purposes or research questions if this paper: (1) to analyse the influence of sustainability on cost and differentiation competitive advantages in the Spanish hotel industry; and (2) to analyse the relationship between sustainability and hotel performance and understand whether this relationship occurs only in the most profitable hotels.

To answer these two research questions, and following the arguments proposed in the literature review section, we propose three hypotheses:

Hypothesis 1: Sustainability is positively associated with cost competitive advantage in hotels.

Hypothesis 2: Sustainability is positively associated with differentiation competitive advantage in hotels.

Hypothesis 3: The relationship between sustainability and performance is significant only in the most profitable hotels (synergistic relationship).

The population analysed to answer the research questions and to test the hypotheses consisted of 3-, 4- and 5-star hotels located in Spain. We decided to study these categories because they are the ones that will have the most resources, enabling them to apply the analysed sustainability measures. Obtained from the Alimarket (2018) database, the population census was 5,071 hotels (of which 2,233 were 3-star, 2,472 were 4-star and 366 were 5-star). We designed a questionnaire and pre-tested it with 14 different respondents: six management-level staff, two representatives of hotel associations, two staff at national tourist knowledge transfer institutions, one tourism policymaker, two tourism scholars and a tourism consultant. The pre-test was used to simplify and contextualise the survey items.

After the pre-test, a structured questionnaire was sent to the whole population by post and by email in two waves. 365 completed questionnaires were received, which means a response rate of $7.20 \%$ and a sampling error of $4.94 \%$. The sample distribution by hotel category was: $38.1 \%$ for 3 -star; $52.3 \%$ for 4 -star; and $8.2 \%$ for 5 -star, while $1.4 \%$ did not disclose the category. $48.6 \%$ of the hotels belonged to hotel chains, while $51.4 \%$ were independent hotels. The average size was 124 rooms.

We aimed to reduce the likelihood of common method bias by adhering to the convention as follows (Conway \& Lance, 2010; Podsakoff et al., 2012). First, the accompanying letter that introduced the questionnaire requested that the hotel manager completed the questions on competitive advantage and performance, while the questions on sustainability were to be answered by the person responsible for this area. Second, we combined perceptual and objective questions in the same questionnaire. Third, we offered construct validity evidence. Finally, we tested for non-response bias, as it is expected that late respondents will be more similar to those who did not answer than will early respondents (Armstrong and Overton, 1977); Pearson's Chi Square and t Student tests were applied between the first and the last third of our data set and the results did not show significant differences between the data sets.

Structural equations model (SEM) based on Partial Least Squares (PLS) is applied to test the hypotheses using SmartPLS 3 software (Ringle et al., 2015). PLS is applied because there are latent constructs in our research model and the PLS approach applies a component-based approach to estimation, thus, placing minimal demands on sample size and residual distributions. PLS is a conservative modelling approach that underestimates path coefficients (Hair et al., 2019), reducing the likelihood of Type I errors in hypothesis testing (Bagozzi et al., 1991). 


\section{JOURNAL OF TOURISM AND SERVICES}

Issue 23, volume 12, ISSN 1804-5650 (Online)

www.jots.cz

\subsection{Measures}

This study analysed composite and reflective perceptual constructs. Sustainability is a composite because it is a construct derived from a theoretical justification; it is expected that there will be a correlation between the three first-order constructs making up a second-order construct, and the firstorder constructs are not replaceable with each other (Henseler, 2017). However, economic practices, environmental practices, social practices, competitive advantages, and hotel perceptual performance are reflective first-order constructs because their items are caused by these constructs, and a high correlation is expected among the items, therefore eliminating an item would not alter the meaning of the construct.

Sustainability is a composite second-order construct formed by three reflective first-order constructs: economic, environmental and social practices. We used a scale proposed by Garay and Font (2013), with each item measured on a 7-point Likert response scale $(1=$ "Strongly disagree", $7=$ "Strongly agree") (Table 1).

Competitive advantage was measured using a scale with nine items that were drawn from various earlier scales proposed by Beal (2000), Govindarajan (1988), Lee and Miller (1996) and Miller (1988) (Table 1), each of which were measured using a seven-point Likert scale. Items were classified according to their corresponding cost and differentiation advantages.

Hotel performance was measured by means of objective and perceptual variables, to triangulate and strengthen the results. The objective hotel performance variables used for each hotel were the occupancy rate, ADR and RevPAR obtained in 2018, which are variables always known to hotel managers. To our knowledge, no other studies have objectively measured the occupancy rate, ADR or RevPAR in a study relating sustainability practices to a hotel's performance. The perceptual performance variables consisted of five items, based on the studies by Bou-Llusar et al. (2009); and Sainaghi et al. (2017). The hotel managers were asked to compare the hotel with its known competitors when evaluating each of the five items, using a scale from 1 ("much worse than its competitors") to 7 ("much better than its competitors") (Table 1).

In addition, three control variables were included to strengthen the model's explanatory power: i) chain affiliation $(0=$ independent; $1=$ chain); ii) number of stars $(3,4$ or 5$)$; and iii) size (number of rooms). It was expected that chain-affiliated hotels, those of a higher star category and those of a greater size, would have more resources to plan and implement sustainability measures in their establishments and would therefore achieve better performance levels.

\subsection{Assessment of the measurement and the structural models}

To test the hypotheses, PLS-SEM is applied. For this reason, both the validity of the measurement model and the structural model must be evaluated. First, the validity of the measurement model is analysed. The measurement model is formed of composite constructs (sustainability) and reflective constructs (economic practices, environmental practices, social practices, competitive advantage and perceptual performance). This means that we can apply traditional validity and reliability criteria (Henseler et al., 2016). Table 1 shows the loadings for each item. The criterion suggests that loadings should be over 0.707 . This is not met by item 1 of economic practices, item 2 of environmental practices or items 2, 6 and 7 of social practices. Nevertheless, it was decided to keep all these items in the analysis because their loads are over 0.6 and their elimination does not improve AVE. Construct reliability is examined in Table 1 and all the values are over 0.7. Convergent validity, measured by AVE, is also included in Table 1 and shows that all the AVE values are over 0.5. Discriminant validity is also checked successfully, based on the Fornell-Larcker and HTMT ${ }_{85}$ criteria (Henseler et al., 2015), (Table 2) and we observe that all the constructs fulfil the discriminant validity requirements. 
Table 1. List of perceptual items and assessment of the measurement model.

\begin{tabular}{|c|c|c|c|c|}
\hline Constructs / items & Loadings & $\begin{array}{c}\text { Composite } \\
\text { reliability }\end{array}$ & AVE & $\begin{array}{c}\text { Cronbach's } \\
\alpha\end{array}$ \\
\hline Sustainability & & 0.909 & 0.770 & 0.853 \\
\hline Economic practices & 0.859 & 0.823 & 0.543 & 0.721 \\
\hline The economic impact of the business on the destination's development is analysed & $0.689 *$ & & & \\
\hline Employees' wages are higher than the average in the industry & 0.741 & & & \\
\hline Bonuses are offered to employees & 0.783 & & & \\
\hline There are staff training programmes & 0.731 & & & \\
\hline Environmental practices & 0.843 & 0.946 & 0.595 & 0.938 \\
\hline The hotel's environmental impact is assessed & 0.754 & & & \\
\hline Actions are implemented to save water and/or energy & $0.700^{*}$ & & & \\
\hline Waste is recycled & 0.727 & & & \\
\hline Environment-friendly products are used & 0.740 & & & \\
\hline Environment-friendly suppliers are chosen & 0.784 & & & \\
\hline Employees are trained in environmental matters & 0.835 & & & \\
\hline Customers are encouraged to save energy and/or water & 0.735 & & & \\
\hline Customers are encouraged to consume ecological products & 0.735 & & & \\
\hline Customers are encouraged to participate in environmental protection initiatives & 0.791 & & & \\
\hline Customers are encouraged to respect the environment inside the hotel & 0.822 & & & \\
\hline $\begin{array}{l}\text { Customers are encouraged to respect the natural environment surrounding the } \\
\text { hotel }\end{array}$ & 0.782 & & & \\
\hline Actions are implemented contributing to preserve the environment & 0.839 & & & \\
\hline Social practices & 0.929 & 0.923 & 0.546 & 0.915 \\
\hline The social impact of the hotel is assessed & 0.790 & & & \\
\hline There is cooperation with social charity projects & $0.641^{*}$ & & & \\
\hline Preservation of the local heritage is promoted & 0.754 & & & \\
\hline Local community development is promoted & 0.797 & & & \\
\hline Gender equality is promoted in human resource practices & 0.803 & & & \\
\hline Work-family conciliation is facilitated among the staff & $0.626^{*}$ & & & \\
\hline Suppliers are chosen with provable social responsibility & $0.668^{*}$ & & & \\
\hline Customers are encouraged to participate in social charity initiatives & 0.747 & & & \\
\hline Respect for the destination's culture and language is actively promoted & 0.790 & & & \\
\hline The facilities exceed the legal requirements regarding accessibility & 0.750 & & & \\
\hline Civic attitude among customers is promoted & 0.754 & & & \\
\hline Cost advantage & & 0.893 & 0.736 & 0.824 \\
\hline Overheads are minimized & 0.802 & & & \\
\hline An attempt is made to improve productivity & 0.883 & & & \\
\hline Efforts are made to obtain economies of scale & 0.887 & & & \\
\hline Differentiation advantage & & 0.911 & 0.633 & 0.883 \\
\hline Creation of a brand image & 0.712 & & & \\
\hline The service offered is of higher quality than that by competitors & 0.828 & & & \\
\hline $\begin{array}{l}\text { A higher number of complementary services are offered, adding value for the } \\
\text { customer }\end{array}$ & 0.844 & & & \\
\hline \multicolumn{5}{|l|}{ The experience offered is better than that by our competitors } \\
\hline Attempts are made to exceed customers' expectations & 0.841 & & & \\
\hline Major innovations are introduced in the service & 0.749 & & & \\
\hline Perceptual performance & & 0.920 & 0.697 & 0.891 \\
\hline Average room occupancy performance & 0.743 & & & \\
\hline Total revenues per available room & 0.872 & & & \\
\hline Gross profit per room & 0.852 & & & \\
\hline Sales volume & 0.868 & & & \\
\hline Market share & 0.833 & & & \\
\hline
\end{tabular}




\section{JOURNAL OF TOURISM AND SERVICES}

Issue 23, volume 12, ISSN 1804-5650 (Online)

www.jots.cz

Secondly, the validity of the structural model is also assessed. The goodness of fit of the first order structural model is SRMR $=0.068<0.08$ and for the second order model is SRMR $=0.060<0.08$ (Henseler et al., 2015). In addition, the VIF values of each predictor in the structural model is higher than 0.20 and lower than 5 (our minimum value is 1 and our maximum value is 1.233). We applied a PLS Predict analysis and the results show that a minority of indicators in the PLS-SEM analysis (only eight of the 20 indicators, or $40 \%$ of them) yield higher prediction errors compared to the naive LM benchmark, which indicates a medium predictive power of the structural model (Shmueli et al., 2019).

Table 2. Discriminant validity.

\begin{tabular}{|c|c|c|c|c|c|c|c|c|}
\hline & \multicolumn{4}{|c|}{$\begin{array}{l}\text { Fornell-Larcker discriminant } \\
\text { validity }\end{array}$} & \multicolumn{4}{|c|}{ HTMT85 validity } \\
\hline & 1 & 2 & 3 & 4 & 1 & 2 & 3 & 4 \\
\hline 1. Sustainability & $(0.878)$ & --- & --- & --- & --- & --- & --- & --- \\
\hline 2. Cost competitive advantage & 0.308 & $(0.858)$ & --- & $\begin{array}{ll}-- \\
\end{array}$ & 0.359 & --- & $\begin{array}{ll}--- \\
\end{array}$ & --- \\
\hline 3. Differentiation competitive advantage & 0.485 & 0.508 & $(0.795)$ & --- & 0.537 & 0.595 & --- & --- \\
\hline 4. Perceptual performance & 0.304 & 0.192 & 0.428 & $(0.835)$ & 0.343 & 0.227 & 0.474 & --- \\
\hline
\end{tabular}

Note: The diagonal values (between brackets) are the square roots of AVE. The other values of the matrix are the correlations between the constructs. To check the discriminant validity, the diagonal values have to be greater than the off-diagonal values. Source: Own research

\section{Results}

In this section we test the hypotheses proposed. All the data provided by the 365 hotels in the sample were used to test all the hypotheses. Table 3 shows the values of the $\beta$ regression coefficients, the t statistical significance and the confidence intervals after applying a bootstrap analysis with 5,000 subsamples. These results in Table 3 show that Hypotheses 1 and 2 are fully supported, i.e., that sustainability significantly explains both $\operatorname{cost}(\beta=0.312, t=5.383, p<0.001)$ and differentiation $(\beta=0.494$, $\mathrm{t}=10.809, \mathrm{p}<0.001)$ advantages in the hotel industry. Furthermore, Table 3 shows that sustainability significantly explains three out of the four performance measures, namely perceptual performance $(\beta=0.273, \mathrm{t}=5.525, \mathrm{p}<0.001), \operatorname{ADR}(\beta=0.153, \mathrm{t}=3.039, \mathrm{p}<0.001)$ and RevPAR $(\beta=0.154, \mathrm{t}=2.996$, $\mathrm{p}<0.001)$, but it does not significantly explain the occupancy rate per room $(\beta=-0.030, t=0.566, p>0.10$ (n.s.)) when we analyse the whole sample.

Concerning the control variables, Table 3 shows that: i) chain affiliation significantly explains sustainability $(\beta=0.150, \mathrm{t}=2.786, \mathrm{p}<0.01)$; ii) star category significantly explains perceptual performance $(\beta=0.118, \mathrm{t}=2.124, \mathrm{p}<0.05)$; and iii) size significantly explains sustainability $(\beta=0.099, \mathrm{t}=1.828, \mathrm{p}<0.05)$ and occupancy rate per room $(\beta=0.264, t=5.365, \mathrm{p}<0.001)$. Therefore, chain affiliation and size are key operational variables to explain sustainability in the hotel industry.

Finally, Table 4 analyses whether hotels with higher performance levels are those where the relationship between sustainability and performance is significant. For this purpose, the sample was divided into eight groups (four pairs because there are four performance variables), depending on whether the hotel analysed was above or below the median (the median was used because it is less sensitive to outliers than the mean); this was done for each of the four performance variables. Then, we ran the same structural model four times, once for each pair (above and below the median) of the four performance variables. Table 4 shows that a significant relationship between sustainability and performance variables is only obtained for those hotels whose perceptual performance $(\beta=0.210$, $\mathrm{t}=2.008, \mathrm{p}<0.05), \operatorname{ADR}(\beta=0.271, \mathrm{t}=2.440, \mathrm{p}<0.01)$ or $\operatorname{RevPAR}(\beta=0.287, \mathrm{t}=2.796, \mathrm{p}<0.01)$ are above the median. Therefore, Hypothesis 3 is supported for these three hotel performance variables, i.e., there is a synergistic relationship between sustainability and performance. 
Table 3. Structural equation modelling results.

\begin{tabular}{|c|c|c|c|c|c|c|c|}
\hline & Sustainability & $\begin{array}{c}\text { Cost } \\
\text { advantage }\end{array}$ & $\begin{array}{c}\text { Differentiation } \\
\text { advantage }\end{array}$ & $\begin{array}{c}\text { Perceptual } \\
\text { performance }\end{array}$ & $\begin{array}{c}\text { Occupancy rate } \\
\text { per room }\end{array}$ & RevPAR & ADR \\
\hline $\mathbf{R}^{2}$ & 0.060 & 0.097 & 0.244 & 0.120 & 0.092 & 0.025 & 0.024 \\
\hline \multicolumn{2}{|l|}{ Paths } & $\beta$ & $\mathbf{t}$ & $\begin{array}{c}95 \% \text { Confidence } \\
\text { interval }\end{array}$ & & & \\
\hline \multicolumn{2}{|l|}{ Sustainability $\rightarrow$ Cost advantage } & $0.312^{* * *}$ & 5.383 & {$[0.209 ; 0.402]$} & & & \\
\hline \multicolumn{2}{|c|}{ Sustainability $\rightarrow$ Differentiation advantage } & $0.494 * * *$ & 10.809 & {$[0.413 ; 0.564]$} & & & \\
\hline \multicolumn{2}{|c|}{ Sustainability $\rightarrow$ Perceptual performance } & $0.273^{* * *}$ & 5.525 & {$[0.181 ; 0.354]$} & & & \\
\hline \multicolumn{2}{|c|}{ Sustainability $\rightarrow$ Occupancy rate per room } & -0.030 n.s. & 0.566 & {$[-0.116 ; 0.058]$} & & & \\
\hline \multicolumn{2}{|c|}{ Sustainability $\rightarrow$ ADR } & $0.153 * * *$ & 3.039 & {$[0.072 ; 0.231]$} & & & \\
\hline \multicolumn{2}{|l|}{ Sustainability $\rightarrow$ RevPAR } & $0.154 * * *$ & 2.996 & {$[0.068 ; 0.234]$} & & & \\
\hline \multicolumn{5}{|l|}{ Control variables } & & & \\
\hline \multicolumn{2}{|l|}{ Chain $\rightarrow$ Sustainability } & $0.150 * *$ & 2.786 & {$[0.058 ; 0.233]$} & & & \\
\hline \multicolumn{2}{|l|}{ Chain $\rightarrow$ Perceptual performance } & 0.046n.s. & 0.853 & {$[-0.043 ; 0.133]$} & & & \\
\hline \multicolumn{2}{|l|}{ Chain $\rightarrow$ Occupancy rate per room } & 0.054n.s. & 1.018 & {$[-0.034 ; 0.141]$} & & & \\
\hline \multicolumn{2}{|l|}{ Chain $\rightarrow$ ADR } & -0.019 n.s. & 0.249 & {$[-0.129 ; 0.108]$} & & & \\
\hline \multicolumn{2}{|l|}{ Chain $\rightarrow$ RevPAR } & -0.017 n.s. & 0.238 & {$[-0.117 ; 0.104]$} & & & \\
\hline \multicolumn{2}{|l|}{ Stars $\rightarrow$ Sustainability } & 0.082n.s. & 1.480 & {$[-0.010 ; 0.173]$} & & & \\
\hline \multicolumn{2}{|l|}{ Stars $\rightarrow$ Perceptual performance } & $0.118^{*}$ & 2.124 & {$[0.025 ; 0.207]$} & & & \\
\hline \multicolumn{2}{|l|}{ Stars $\rightarrow$ Occupancy rate per room } & 0.049n.s. & 0.814 & {$[-0.049 ; 0.147]$} & & & \\
\hline \multicolumn{2}{|l|}{ Stars $\rightarrow$ ADR } & 0.026n.s. & 0.176 & {$[-0.076 ; 0.415]$} & & & \\
\hline \multicolumn{2}{|l|}{ Stars $\rightarrow$ RevPAR } & 0.038n.s. & 0.290 & {$[-0.065 ; 0.366]$} & & & \\
\hline \multicolumn{2}{|l|}{ Size $\rightarrow$ Sustainability } & $0.099 *$ & 1.828 & {$[0.007 ; 0.184]$} & & & \\
\hline \multicolumn{2}{|l|}{ Size $\rightarrow$ Perceptual performance } & 0.050n.s. & 1.152 & {$[-0.021 ; 0.120]$} & & & \\
\hline \multicolumn{2}{|l|}{ Size $\rightarrow$ Occupancy rate per room } & $0.264 * * *$ & 5.365 & {$[0.176 ; 0.338]$} & & & \\
\hline \multicolumn{2}{|l|}{ Size $\rightarrow$ ADR } & -0.056 n.s. & 1.487 & {$[-0.103 ; 0.015]$} & & & \\
\hline \multicolumn{2}{|l|}{ Size $\rightarrow$ RevPAR } & -0.050 n.s. & 1.115 & {$[-0.101 ; 0.038]$} & & & \\
\hline
\end{tabular}




\section{JOURNAL OF TOURISM AND SERVICES}

Issue 23, volume 12, ISSN 1804-5650 (Online)

www.jots.cz

Table 4. Relationship between hotel performance and sustainability depending on the median of each performance variable.

\begin{tabular}{|l|c|c|c|c|c|c|}
\cline { 2 - 7 } \multicolumn{1}{c|}{} & \multicolumn{4}{c|}{$\begin{array}{c}\text { Below the median of the } \\
\text { corresponding performance variable }\end{array}$} & \multicolumn{3}{c|}{$\begin{array}{c}\text { Above the median of the } \\
\text { corresponding performance variable }\end{array}$} \\
\cline { 2 - 7 } & $\beta$ & $\mathrm{t}$ & $\begin{array}{c}95 \% \text { Confidence } \\
\text { interval }\end{array}$ & $\beta$ & $\mathrm{t}$ & $\begin{array}{c}95 \% \text { Confidence } \\
\text { interval }\end{array}$ \\
\hline $\begin{array}{l}\text { Sustainability } \\
\begin{array}{l}\rightarrow \text { Perceptual } \\
\text { performance }\end{array}\end{array}$ & 0.185 n.s. & 1.631 & {$[-0.067 ; 0.328]$} & $0.210^{*}$ & 2.008 & {$[0.024 ; 0.363]$} \\
\hline $\begin{array}{l}\text { Sustainability } \\
\rightarrow \text { Occupancy } \\
\text { rate per room }\end{array}$ & $-0.124 \mathrm{n} . \mathrm{s}$. & 1.544 & {$[-0.248 ; 0.016]$} & $-0.071 \mathrm{n} . \mathrm{s}$. & 0.756 & {$[-0.220 ; 0.086]$} \\
\hline $\begin{array}{l}\text { Sustainability } \\
\rightarrow \text { ADR }\end{array}$ & 0.122 n.s. & 1.506 & {$[-0.006 ; 0.256]$} & $0.271 * *$ & 2.440 & {$[0.044 ; 0.419]$} \\
\hline $\begin{array}{l}\text { Sustainability } \\
\rightarrow \text { RevPAR }\end{array}$ & -0.017 n.s. & 0.175 & {$[-0.175 ; 0.139]$} & $0.287 * *$ & 2.796 & {$[0.094 ; 0.434]$} \\
\hline
\end{tabular}

Note: These analyses are carried out applying significance levels for one-tailed test. The analyses also include the control variables. We based this analysis on the median because it is less sensitive to outliers than the mean. n.s. $=$ Nonsignificant. ${ }^{*}$ $\mathrm{p}<0.05,{ }^{* *} \mathrm{p}<0.01,{ }^{* * *} \mathrm{p}<0.001$

Source: Own research

\section{Discussion}

We have responded to the call for further studies to specifically research the impact of sustainability on organisational performance (Rhou \& Singal, 2020). This study has a dual purpose: i) to study the link between sustainability, and cost and differentiation competitive advantages; and ii) to analyse the synergistic relationship between sustainability and performance. We have shown that multiple theories explain the motivations for organisations to engage in sustainability. What becomes clear is that the same sustainability action can be undertaken for different reasons by different organisations, or indeed the same organisation can have multiple reasons for engaging in one single practice. Therefore, motivation theories and sustainability practices are not mutually exclusive, which adds to the complexity of the analysis.

This complexity can be viewed, however, in a positive light: hotels can potentially gain cost competitive advantages from reducing wasteful resource consumption and can be astute enough to gain differentiation competitive advantages through customer-driven sustainability actions. The profits generated through acting on these competitive advantages can be seen as short-term gains or can be reinvested in improved technologies and resources that lead to further cost savings that address, to a greater extent, their stakeholder needs. Further research is needed to know whether such relationships can be explained by the slack resource theory, which suggests that higher revenues provide resources to invest in sustainability, or by the good governance theory, which suggests that generally well-managed hotels will include sustainability as part of their governance plans.

Our results indicate a positive relationship between sustainability and competitive advantages. The results show that cost reduction and differentiation are two major reasons why managers might be interested in developing sustainability practices. The results are consistent with the resource-based view (Barney, 1991; Garay \& Font, 2012, 2013) and the institutional theory (Farha et al., 2018), as hotels use their resources and capabilities to obtain competitive advantage and as a way to gain legitimacy among their stakeholders. The relationship between sustainability and cost competitive advantage in the data 


\section{JOURNAL OF TOURISM AND SERVICES}

Issue 23, volume 12, ISSN 1804-5650 (Online)

www.jots.cz

could have arisen because the questionnaire respondents are conscious that there are potential ecosavings from sustainability practices. Our results about the influence of sustainability on cost competitive advantage coincide with those found earlier (Bohdanowicz et al., 2011; Garay \& Font, 2012; Garay et al., 2019; Wang et al., 2020). Regarding the differentiation advantage, the results show that sustainability practices may impact positively on stakeholders, such as employees, customers, suppliers and the government. Therefore, it is possible to conclude in this study that sustainability capable of significantly improving levels of hotel differentiation. These results also coincide with previous studies (Ahmed et al., 2019; García-Rodríguez \& Armas-Cruz, 2007; Holotová et al., 2020; Inoue \& Lee, 2011; Kang et al., 2010; Ghaderi et al., 2019; Lee \& Park, 2009; Lu et al., 2020; Streimikiene \& Ahmed, 2021; Theodoulidis et al., 2017).

Furthermore, some studies have analysed the link between sustainability practices and performance in the hotel industry (Ghaderi et al., 2019; Inoue \& Lee, 2011; Theodoulidis et al., 2017), but very few (Lee \& Park, 2009; Moneva et al, 2020, Singal, 2014) have analysed whether the significant relationship between sustainability and performance really only happens in companies that are more profitable or if this relationship is always significant. Our results contribute showing that hotels with performance levels above the median are those in which a significant relationship between sustainability and performance really exists. It is significant to note that hotels driven to maximise their occupancy rates do not engage in more than average sustainability practices, while those hotels that are driven to maximise their average daily rate (ADR), and/or to fill their available rooms at an average rate (RevPAR), do. Therefore, the possible symbiotic relationship between sustainability and performance measures in a sort of virtuous circle (Orlitzky et al., 2003) (proposed by the slack resources and synergy theories) seems to happen only among companies that are more profitable. In fact, this relationship is not significant in the sub-sample of hotels that are less profitable. These findings may be due to the fact that the more profitable companies may have developed other capabilities that can make the relationship between sustainability and performance effectively significant. These research findings are in line with those obtained by Claveras (2015), Lee \& Park (2009) and Singal (2014). Therefore, answering the two research questions proposed in the introduction, it can be stated that "it pays to be sustainable" and "the most profitable hotels are the most sustainable".

This paper offers several academic implications. First, we studied the relationship between sustainability and performance, in a sort of synergistic circle, and the relationship between sustainability and cost and differentiation competitive advantages in a single model. This study offers academic evidence on the strong relationships that exist between these variables. Second, some studies have analysed the connection between sustainability practices and performance in this industry (Ghaderi et al., 2019; Inoue \& Lee, 2011; Theodoulidis et al., 2017), but only one study (Lee \& Park, 2009) has analysed whether higher performance could lead to more sustainability practices. This study shows that the relationship between sustainability and performance only happens for those hotels whose hotel performance is higher than the median. Third, our research contributes to the slack resources theory by answering the following question: is it possible to identify whether, in the face of increased performance, hotel managers would increase their interest in the development of sustainable practices as a way to obtain positive synergies between the two variables? Finally, measurement scales and contextual variables appropriate to the hotel industry have been adopted, to ensure a better understanding of the connection between sustainability practices and performance for this industry.

This study offers several managerial implications for hotels. First, we show that there are two powerful reasons to invest in sustainability practices i) to reduce costs, and ii) to differentiate the hotel by improving its reputation and legitimacy. Second, obtaining competitive advantage in differentiation may also lead to improved performance in a hotel. Third, the two items best valued by hotel managers to reduce the hotel costs were (see Table 1): "efforts are made to obtain economies of scale", and "an attempt is made to improve productivity". Regarding differentiation, the items best valued by managers in this study were (see Table1): "a higher number of complementary services are offered", "adding value 


\section{JOURNAL OF TOURISM AND SERVICES}

Issue 23, volume 12, ISSN 1804-5650 (Online)

www.jots.cz

for the customer", "the experience offered is better than that by our competitors", and "the service offered is of higher quality than that by competitors".

Fourth, sustainability studies have analysed how one pillar of sustainability (the environment) influences competitive advantage in costs and differentiation. This paper considers all three sustainability pillars: economic, environmental and social, which makes it possible to offer hotel managers a wide array of sustainability practices that may have a positive influence on their hotel's competitiveness (Garay \& Font, 2012).

Fifth, this study identifies the most important sustainability practices in each of its three axes to help prioritize business actions in the search for competitive advantage (see Table 1). In this sense, in the economic pillar (offering bonuses to employees, the employees' wages being above the average in the industry, and the existence of staff training programmes), in the environmental pillar (implementing actions that contribute to preserving the environment, training employees in environmental management issues, and encouraging customers to respect the environment inside the hotel), and in the social pillar (promoting gender equality in human resource practices, local community development, and respect for the destination's culture and language). If managers implement these sustainability practices in their hotels, they may improve their competitiveness and their performance.

\section{Conclusion}

In conclusion, although sustainability has been analysed in the general management literature, there are far fewer studies applied to the hotel industry. Within the studies applied to the hotel industry, the vast majority only analyse environmental sustainability in isolation. For this reason, we consider important to complete the previous research including economic and social sustainability and offer specific empirical evidence to the hotel managers. We can conclude that the most important dimension for hotel managers surveyed is social sustainability, followed by economic and environmental sustainability. This may be a sign that environmental sustainability has already been established in the Spanish tourism industry for years ago and it is managed in a more mature phase. The items that best explain each type of sustainability are also identified to prioritize management efforts.

In addition, the research findings indicate that sustainability has a significant and positive influence on cost and differentiation advantages, confirming the results of most of the previous research. Therefore, it continues to be shown that sustainability is very relevant to control the costs of hotels and improve their levels of differentiation through the improvement of their reputation and the guest experience.

Another conclusion is that this study establishes a synergistic relationship between sustainability and performance. To do this, the direct relationship between both variables is analysed. The result is that only hotels with performance levels above the median are those in which a significant relationship between sustainability and performance really exists. In addition, this result occurs for the perceptual performance and for the objective variables of hotel performance related to the increase in room rates (ADR and RevPAR). Therefore, an important contribution of this study is that this result defends a tourism management model where the sustainability must be based on the improvement of the guest experience through differentiation that will mean an increase in room rates instead of mass tourism based on occupancy.

Finally, in order to have an in-depth understanding of the relationship between sustainability, competitive advantages and performance in the hotel industry, future research is needed. For example, within this study, performance has been measured from a perceptual and an objective point of view; this has, at times, led to different results, showing that the choice of a specific measurement unit may have an impact on the results obtained. From an objective point of view, occupancy rate, ADR and RevPAR are short-term measurements that only consider past performance. Future studies might wish to consider 


\section{JOURNAL OF TOURISM AND SERVICES}

Issue 23, volume 12, ISSN 1804-5650 (Online)

www.jots.cz

short- and long-term performance measurements specific to the hotel industry, to analyse if sustainability practices have a positive influence on both variables, and to include mediating or moderating variables of the relationship between sustainability and performance.

Acknowledgments: This work was supported by the Spanish Ministry of Economy and Competitiveness (grant number ECO2015-67310P).

\section{References}

1. Abughniem, M. S., Al Aishat, M. H., \& Hamdan, A. M. (2019). Corporate sustainability as an antecedent to the financial performance: an empirical study. Polish Journal of Management Studies, 20(2), 35-44. https://doi.org/10.17512/pims.2019.20.2.03

2. Ahmed, U., AlZgool, M. D. H., \& Shah, S. M. M. (2019). The impact of green human resource practices on environmental sustainability. Polish Journal of Management Studies, 20(1), 9-18. https://doi.org/10.17512/pjms.2019.20.1.01

3. Al-Ali Mubarak, Y. M., Gorgenyi-Hegyes, E., \& Fekete-Farkas, M. (2020). Perceived corporate sustainability practices and performance of small and medium enterprises (SMES) in Qatar. Polish Journal of Management Studies, 22(1), 26-42. https://doi.org/10.17512/pjms.2020.22.1.02

4. Alimarket (2018). Hoteles. Base de datos. https://www.alimarket.es/hoteles

5. Attila, A. T. (2016). The impact of the hotel industry on the competitiveness of tourism destinations in Hungary. Journal of Competitiveness, 8(4), 85-104. https://doi.org/10.7441/joc.2016.04.06

6. Bagozzi, R.P., Yi, Y., \& Singh, S. (1991). On the use of structural equation models in experimental designs: Two extensions. International Journal of Research Marketing, 8(2), 125-140. https://doi.org/10.1016/0167-8116(91)90020-8

7. Barney, J. B. (2001). Resource-based theories of competitive advantage: A ten-year retrospective on the resource-based view. Journal of Management, 27(6), 643-650. https://doi.org/10.1177/014920630102700602

8. Beal, R. M. (2000). Competing effectively: Environmental scanning, competitive strategy, and organizational performance in small manufacturing firms. Journal of Small Business Management, 38, 27-47.

9. Berezan, O., Millar, M., \& Raab, C. (2014). Sustainable hotel practices and guest satisfaction levels. International Journal of Hospitality \& Tourism Administration, 15(1), 1-18. https://doi.org/10.1080/15256480.2014.872884

10. Bohdanowicz, P., Zientara, P., \& Novotna, E. (2011). International hotel chains and environmental protection: an analysis of Hilton's we care! programme (Europe, 2006-2008). Journal of Sustainable Tourism, 19(7), 797-816. https://doi.org/10.1080/09669582.2010.549566

11. Bou-Llusar, J. C., Escrig-Tena, A. B., Roca-Puig, V, \& Beltrán-Martín, I. (2009). An empirical assessment of the EFQM Excellence Model: Evaluation as a TQM framework relative to the MBNQA Model. Journal of Operations Management, 27, 1-22. https://doi.org/10.1016/i.jom.2008.04.001

12. Calveras, A. (2015). Corporate social responsibility strategy in the hotel industry: evidence from the Balearic Islands. International Journal of Tourism Research, 17, 399-408. https://doi.org/10.1002/itr.2007

13. Conway, J. M., \& Lance, C. E. (2010). What reviewers should expect from authors regarding common method bias in organizational research. Journal of Business and Psychology, 25(3), 325-334. https://doi.org/10.1007/s10869-010-9181-6 


\section{JOURNAL OF TOURISM AND SERVICES}

Issue 23, volume 12, ISSN 1804-5650 (Online)

www.jots.cz

14. Farha, A. K. A., Al-Kwifi, O. S., \& Ahmed, Z. U. (2018). Deploying partial least squares to investigate the influence of managerial assumptions on corporate social responsibility in the hotel industry. Journal of Hospitality and Tourism Technology, 9(3), 471-486. https://doi.org/10.1108/JHTT-09-2017-0099

15. Farooq, R., Zhang, Z., Talwar, S., \& Dhir, A. (2021). Do green human resource management and self-efficacy facilitate green creativity? A study of luxury hotels and resorts. Journal of Sustainable Tourism, 1-22. https://doi.org/10.1080/09669582.2021.1891239

16. Fernández-Gámez, M. Á., Gutiérrez-Ruiz, A. M., Becerra-Vicario, R., \& Ruiz-Palomo, D. (2020). The impact of creating shared value on hotels online reputation. Corporate Social Responsibility and Environmental Management, 27(5), 2201-2211. https://doi.org/10.1002/csr.1958

17. Font, X., Garay, L., \& Jones, S. (2016). A social cognitive theory of sustainability empathy. Annals of Tourism Research, 58, 65-80. https://doi.org/10.1016/i.annals.2016.02.004

18. Font, X., \& McCabe, S. (2017). Sustainability and marketing in tourism: Its contexts, paradoxes, approaches, challenges and potential. Journal of Sustainable Tourism, 25(7), 869-883. https://doi.org/10.1080/09669582.2017.1301721

19. Garay, L., \& Font, X. (2012). Doing good to do well? Corporate social responsibility reasons, practices and impacts in small and medium accommodation enterprises. International Journal of Hospitality Management, 31, 329-337. https://doi.org/10.1016/j.ijhm.2011.04.013

20. Garay, L., \& Font, X. (2013). Corporate social responsibility in tourism small and medium enterprises evidence from Europe and Latin America. Tourism Management Perspectives, 7, 38-46. https://doi.org/10.1016/i.tmp.2013.03.002

21. Garay, L., Font, X., \& Corrons, A. (2019). Sustainability-oriented innovation in tourism: An analysis based on the decomposed theory of planned behavior. Journal of Travel Research, 58(4), 622-636. https://doi.org/10.1177/0047287518771215

22. Garriga, E., \& Melé, D. (2004). Corporate social responsibility theories: Mapping the territory. Journal of Business Ethics, 53(1-2), 51-71. https://doi.org/10.1023/B:BUSI.0000039399.90587.34

23. García-Rodríguez, F. J., \& Armas-Cruz, Y. (2007). Relation between social-environmental responsibility and performance in hotel firms. International Journal of Hospitality Management, 26, 824-839. https://doi.org/10.1016/j.ijhm.2006.08.003

24. Ghaderi, Z., Mirzapour, M., Henderson, J. C., \& Richardson, S. (2019). Corporate social responsibility and hotel performance: a view from Tehran, Iran. Tourism Management Perspectives, 29, 41-47. https://doi.org/10.1016/j.tmp.2018.10.007

25. González-Rodríguez, M. R., Martín-Samper, R. C., Köseoglu, M. A., \& Okumus, F. (2019). Hotels' corporate social responsibility practices, organizational culture, firm reputation, and performance. Journal of Sustainable Tourism, 27(3), 398-419. https://doi.org/10.1080/09669582.2019.1585441

26. Govindarajan, V. (1988). A contingency approach to strategy implementation at the business-unit level: Integrating administrative mechanisms with strategy. Academy of Management Journal, 31, 828153. https://doi.org/10.2307/256341

27. Hair, J. F., Risher, J. J., Sarstedt, M., \& Ringle, C. M. (2019). When to use and how to report results of PLS-SEM. European Business Review, 31(1), 2-24. https://doi.org/10.1108/EBR-112018-0203

28. Henseler, J., Hubona, G., \& Ray, P. A. (2016). Using PLS path modeling in new technology research: Updated guidelines. Industrial Management \& Data Systems, 116(1), 2-20. https://doi.org/10.1108/IMDS-09-2015-0382

29. Henseler, J., Ringle, R. M., \& Sarstedt, M. (2015). A new criterion for assessing discriminant validity in variance-based structural equation modelling. Journal of the Academy of Marketing, 43, 115 135. https://doi.org/10.1007/s11747-014-0403-8 
30. Henseler, J. (2017). Bridging design and behavioral research with variance-based structural $\begin{array}{llll}\text { equation modeling. Journal of } & \text { Advertising, 46(1), }\end{array}$ https://doi.org/10.1080/00913367.2017.1281780

31. Holotová, M., Nagyová, L., \& Holota, T. (2020). The impact of environmental responsibility on changing consumer behaviour - sustainable market in Slovakia. Economics and Sociology, 13(3), 8496. https://doi:10.14254/2071-789X.2020/13-3/6

32. Inoue, Y., \& Lee, S. (2011). Effects of different dimensions of corporate social responsibility on corporate financial performance in tourism-related industries. Tourism Management, 32, 790-804. https://doi.org/10.1016/j.tourman.2010.06.019

33. Jurigová, Z. \& Lencsésová, Z. (2015). Monitoring system of sustainable development in cultural and mountain tourism destinations. Journal of Competitiveness, 7(1), 35-52. https://doi.org/10.7441/joc.2015.01.03

34. Jurigová, Z., Tučková, Z., \& Kuncová, M. (2016). Economic sustainability as a future phenomenon: moving towards a sustainable hotel industry. Journal of Security and Sustainability, 6(1), 103-112. http://dx.doi.org/10.9770/jssi.2016.6.1(7)

35. Kang, K. H., Lee, S., \& Huh, C. (2010). Impacts of positive and negative corporate social responsibility activities on company performance in the hospitality industry. International Journal of Hospitality Management, 29, 72-82. https://doi.org/10.1016/j.ijhm.2009.05.006

36. Kuo, F. I., Fang, W. T., \& LePage, B. A. (2021). Proactive environmental strategies in the hotel industry: eco-innovation, green competitive advantage, and green core competence. Journal of Sustainable Tourism, 1-22. https://doi.org/10.1080/09669582.2021.1931254

37. Lee, J., \& Miller, D. (1996). Strategy, environment and performance in two technological contexts: Contingency theory in Korea. Organization Studies, 17, $729-750$. https://doi.org/10.1177/017084069601700502

38. Lee, S., \& Park, S-Y. (2009). Do socially responsible activities help hotels and casinos achieve their financial goals? International Journal of Hospitality Management, 28, 105-112. https://doi.org/10.1016/i.ijhm.2008.06.003

39. Loureiro, S. M. C., Guerreiro, J., \& Han, H. (2021). Past, present, and future of pro-environmental behavior in tourism and hospitality: a text-mining approach. Journal of Sustainable Tourism, 1-21. https://doi.org/10.1080/09669582.2021.1875477

40. Lu, J., Ren, L., Zhang, C., Wang, C., Shahid, A., \& Streimikis, J. (2020). The influence of a firm's CSR initiatives on brand loyalty and brand image. Journal of Competitiveness, 12(2), 106-124. https://doi.org/10.7441/joc.2020.02.07

41. Miller, D. (1988). Relating Porter's business strategies to environment and structure: Analysis and performance implications. Academy of Management Journal, 31, 280-308. https://doi.org/10.2307/256549

42. Moneva, J. M., Bonilla-Priego, M. J., \& Ortas, E. (2020). Corporate social responsibility and organisational performance in the tourism sector. Journal of Sustainable Tourism, 28(6), 853-872. https://doi.org/10.1080/09669582.2019.1707838

43. Orlitzky, M., Schmidt, F. L., \& Rynes, S. L. (2003). Corporate social and financial performance: a meta-analysis. Organization Studies, 24(3), 403-441. https://doi.org/10.1177/0170840603024003910

44. Palacios-Florencio, B., García del Junco, J., Castellanos-Verdugo, M., \& Rosa-Díaz, I. M. (2018). Trust as mediator of corporate social responsibility, image and loyalty in the hotel sector. Journal of Sustainable Tourism, 26(7), 1273-1289. https://doi.org/10.1080/09669582.2018.1447944

45. Peloza, J., \& Papania, L. (2008). The missing link between corporate social responsibility and financial performance: Stakeholder salience and identification. Corporate Reputation Review, 11(2), 169-181. https://doi.org/10.1057/crr.2008.13 


\section{JOURNAL OF TOURISM AND SERVICES}

Issue 23, volume 12, ISSN 1804-5650 (Online)

www.jots.cz

46. Pham, N. T., Chiappetta Jabbour, C. J., Vo-Thanh, T., Huynh, T. L. D., \& Santos, C. (2020). Greening hotels: does motivating hotel employees promote in-role green performance? The role of culture. Journal of Sustainable Tourism, 1-20. https://doi.org/10.1080/09669582.2020.1863972

47. Podsackoff, P. M., MacKenzie, S. B., \& Podsakoff, N. P. (2012). Sources of method bias in social science research and recommendations on how to control it. Annual Review of Psychology, 63, 539569. https://doi.org/10.1146/annurev-psych-120710-100452

48. Ramanathan, R., Ramanathan, U. \& Zhang, Y. (2016). Linking operations, marketing and environmental capabilities and diversification to hotel performance: A data envelopment analysis approach. International Journal of Production Economics, 176, 111-122. https://doi.org/10.1016/j.ijpe.2016.03.010

49. Ringle, C. M., Wende, S., \& Becker, J. A. (2015). SmartPLS 3. Boenningstedt: SmartPLS GmbH, http://www.smartpls.com.

50. Rhou, Y., \& Singal, M. (2020). A review of the business case for CSR in the hospitality industry. International Journal of Hospitality Management, 102330. https://doi.org/10.1016/j.ijhm.2019.102330

51. Sainaghi, R., Phillips P., \& Zavarrone, E. (2017). Performance measurement in tourism firms: A content analytical meta-approach. Tourism Management, 59, 36-56. https://doi.org/10.1016/j.tourman.2016.07.002

52. Sánchez-Medina, P. S., Díaz-Puichardo, R., \& Cruz-Bautista, M. (2016). Stakeholder influence on the implementation of environmental management practices in the hotel industry. International Journal of Tourism Research, 18, 387-398. https://doi.org/10.1002/jtr.2056

53. Shmueli, G., Sarstedt, M., Hair, J. F., Cheah, J.-H., Ting, H., Vaithilingam, S., Ringle, C. M. (2019). Predictive model assessment in PLS-SEM: guidelines for using PLSpredict. European Journal of Marketing, 53, 2322-2347. https://doi.org/10.1108/EJM-02-2019-0189

54. Singal, M. (2014). The link between firm financial performance and investment in sustainability initiatives. Cornell Hospitality Quarterly, 55(1), 19-30. https://doi.org/10.1177/1938965513505700

55. Stojanovic, A., Milosevic, I., Arsic, S., Urosevic, S., \& Mihaljovic, I. (2020). Corporate social responsibility as a determinant of employee loyalty and business performance. Journal of Competitiveness, 12(2), 149-166. https://doi.org/10.7441/joc.2020.02.09

56. Streimikiene, D., \& Ahmed, R. R. (2021). The integration of corporate social responsibility and marketing concepts as a business strategy: evidence from SEM-based multivariate and TodaYamamoto causality models. Oeconomia Copernicana, 12(1), 125-157. https://doi.org/10.24136/oc.2021.006

57. Suárez-Cebador, M., Ruio-Romero, J. C., Pinto-Contreiras, J., \& Gemar, G. (2018). A model to measure sustainable development in the hotel industry: A comparative study. Corporate Social Responsibility and Environmental Management, 25, 722-732. https://doi.org/10.1002/csr.1489

58. Tang, Y. H., Amran, A., \& Goh, Y. N. (2014). Environmental management practices of hotels in Malaysia: Stakeholder perspective. International Journal of Tourism Research, 16, 586-595. https://doi.org/10.1002/jtr.1952

59. Teng, C.-C., Horng, J.-S., \& Hu, I.-C. (2015). Hotel environmental management decisions: the stakeholder perspective. International Journal of Hospitality \& Tourism Administration, 16(1), 78-98. https://doi.org/10.1080/15256480.2015.991991

60. Theodoulidis, B., Diaz, D., Crotto, F., \& Rancati, E. (2017). Exploring corporate social responsibility and financial performance through stakeholder theory in the tourism industries. Tourism Management, 62, 173-188. https://doi.org/10.1016/j.tourman.2017.03.018

61. Vu, H. M, \& Ngo, V. M. (2019). Strategy development from triangulated viewpoints for a fast growing destination toward sustainable tourism development - a case of Phu Quoc Islands in Vietnam. Journal of Tourism and Services, 10(18), 117-140. https://doi.org/10.29036/jots.v10i18.86 
62. Waddock, S. A., \& Graves, S. B. (1997). The corporate social performance-financial performance link. Strategic Management Journal, 18(4), 303-319. https://doi.org/10.1002/(SICI)10970266(199704)18:4<303::AID-SMJ869>3.0.CO;2-G

63. Wang, Y., Font, X., \& Liu, J. (2020). Antecedents, mediation effects and outcomes of hotel ecoinnovation practice. International Journal of Hospitality Management, 85, 102345. https://doi.org/10.1016/i.ijhm.2019.102345

64. Wikhamn, W. (2019). Innovation, sustainable HRM and customer satisfaction. International Journal of Hospitality Management, 76, 102-110. https://doi.org/10.1016/j.ijhm.2018.04.009

65. Zhu, Y., Sun, L-Y., Leung, S. M. (2014). Corporate social responsibility, firm reputation, and firm performance: the role of ethical leadership. Asia Pacific Journal of Management, 31, 925-947. https://doi.org/10.1007/s10490-013-9369-1

\section{Brief description of Authors:}

\section{Dr Jorge Pereira-Moliner, Professor \\ ORCID ID: 0000-0001-7669-8837}

Business Management Department. Universidad de Alicante, Spain.

Email: jorge.pereira@ua.es

His $\mathrm{Ph}$. D. dissertation was an analysis of strategic groups in the hotel industry. His current research includes strategic management, quality management, environmental management, and sustainability in the tourism industry.

\section{Dr María D. López-Gamero, Professor \\ ORCID ID: 0000-0003-1574-6449}

Business Management Department. Universidad de Alicante, Spain.

Email: md.lopez@ua.es

Her Ph. D. dissertation was an analysis of the relationship between environmental management and firm performance. Her current research includes strategic management, sustainable tourism, environmental management and its relationship with quality management and organizational design.

\section{Dr Xavier Font, Professor.}

ORCID ID: 0000-0003-1770-6213

School of Hospitality and Tourism Management, University of Surrey, UK; and

School of Business and Economics, UiT. The Arctic University of Norway, Tromsø, Norway.

Email: x.font@surrey.ac.uk

He researches and develops methods of sustainable tourism production and consumption.

\section{Dr Jose F. Molina-Azorín, Professor \\ ORCID ID: 0000-0002-6337-0514}

Business Management Department. Universidad de Alicante, Spain.

Email: jif.molina@ua.es

His research focuses on strategic management and environmental management, specifically the determinants of firm performance, the competitive effects of environmental management and the relationship between competitive strategy and organizational design. His current research interests are also focused on mixed methods research.

\section{Dr Juan José Tarí, Professor}

ORCID ID: 0000-0003-4280-5264 


\section{JOURNAL OF TOURISM AND SERVICES}

Issue 23, volume 12, ISSN 1804-5650 (Online)

www.jots.cz

Business Management Department. Universidad de Alicante, Spain.

Email: ji.tari@ua.es

His $\mathrm{Ph}$. D. dissertation was an analysis of quality management. His current research includes Total Quality Management and its relationship with sustainability, environmental management, organization design, innovation and higher education.

\section{Dr Eva M. Pertusa-Ortega, Associate Professor}

ORCID ID: 0000-0002-9396-4348

Business Management Department. Universidad de Alicante, Spain.

Email: eva.pertusa@ua.es

Her Ph. D. dissertation was an analysis of the relationship between organizational design and competitiveness. Her current research includes organizational design and its relationship with environmental and quality management, and the study of organizational and individual ambidexterity. 